\title{
Kuzularda Yaşama Gücünün İyileştirilmesi
}

\author{
Mehmet KOYUNCU*, Yağmur DUYMAZ \\ Uludağ Üniversitesi, Ziraat Fakültesi, Zootekni Bölümü, Bursa
}

*İletişim (correspondence): e-posta: koyuncu@uludag.edu.tr ; Tel: +90 (224)2941556, Fax: +90 (224)4428152

Gönderim tarihi (Received): 13 Ağustos 2017; Kabul tarihi (Accepted): 25 Eylül 2017

$\ddot{O} z$

Koyunculuk işletmelerinde geliri etkileyen önemli faktörlerin başında üreme performansı ve kuzuların yaşama gücü gelmektedir. Koyun başına doğan kuzu sayısı bir işletmede ekonomik açıdan önemli bir özelliktir. Bu nedenle, doğum öncesi, doğum sırasında ve doğum sonrası gebe koyunların ve kuzuların bakımı için çok çaba gösterilmelidir. Kuzularda yaşama gücünü etkileyen başlıca faktörlerin farkındalığı, gereksiz kayıpların da önüne geçebilecektir. Bu faktörlerin bazıları doğum tipi, cinsiyet, doğum ağırlığı, annenin kondisyonu ve beslenmesi ve de mevsim olarak sıralanabilir. Genel olarak, en yüksek kuzu ölüm oranı özellikle ilk haftalar olmak üzere doğumdan sütten kesime kadarki zaman diliminde görülmektedir. Yapılan araştırmalar ve deneyimler, kuzuların yaklaşık \% 20'sinin sütten kesimden önce öldüğünü ve bu kayıpların \% 80'inin yaşamın ilk 10 gününde yaşandığını göstermektedir. Kuzularda yaşama gücünü iyileştirmek ekonomik ve uzun vadeli genetik bir çalışmayı gerektirir. Bu kapsamda, kuzularda yaşama gücüne ektili olan faktörler ve bunun geliştirilmesi noktasında dikkate alınması gerekli noktalar üzerinde durulmuştur.

Anahtar kelimeler: Kuzu, yaşama gücü, sürü yönetimi, sütten kesim

\section{Improving Lamb Survival}

\begin{abstract}
Reproduction performance and lambs survival rate are the most important traits influencing income in shepherd. The number of lambs born per ewe is certainly an economically important trait in a sheep enterprise. Therefore, a great deal of effort should be put toward the care of pregnant ewes and their lambs before, during, and after birth. Awareness of major factors affecting lamb survival will avoid unnecessary loss. These factors can be listed such as type of birth, sex, birth weight, condition and nutritional status of the dam and season. Generally, highest lamb mortality occurs within the first week of birth and from birth to weaning. Researches and experiences show that approximately $20 \%$ of the lambs died before the weaning and $80 \%$ of these losses were experienced in the first 10 days of life. As a result of improving the survival of neonatal lamb is essential for the economically and long-term genetic improvement. In this context, the factors which affect the viability of lambs and taken into account in the development of this point has focused on the required spots.
\end{abstract}

Keywords: Lamb, survival, flock management, weaning

\section{Giriş}

Kuzuların yaşama gücü, koyunların genel üreme performansı üzerinde direkt bir etkiye sahip olmasının yanında, hayvan refahı noktasında da önemli bir göstergeyi oluşturması ile sürülerde büyüme, karlılı ve sürdürülebilirliğin temel göstergesidir (Mellor ve Stafford, 2004). Bu kriter üzerine hem genetik hem de yönetsel faktörler önemli rol oynamaktadır (Hinch ve Brien, 2014). Özellikle yönetsel faktörler içinde önemli bir yer tutan gebeliğin son döneminde koyunların doğru beslenmesi, yavrunun uterus içi gelişimi ve buna bağlı olarak doğum sonrası hayatta kalma noktasında önemlidir. Bu durum ile ilişkili olarak gebeliğin farklı evrelerinde koyunların vücut kondisyon skorları incelenmiş olmakla beraber, özellikle mikro besin öğelerinin oynadığı kritik rol hakkında bugün bile çok az şey bilinmektedir.
Koyun yetiştiricilerinin en çok karşılaştığı yönetim zorluklarından biri yeni doğan kuzuların canlı olması ve yaşatılmalarında devamlılığının sağlamasıdır (Anonim, 2017a). İşletmelerde verimliliği yükseltmede temel amaç, bir anaç başına doğan kuzu sayısı ve dönem içinde kayıpları azaltarak büyütülen kuzu sayısını arttırmaktır. Ancak bu durumun önemi birçok ülkede olduğu gibi ülkemizde de tam olarak kavranamamıştır. Diğer taraftan kuzu kayıpları sadece ekonomik açıdan değerlendirilmemeli aynı zamanda hayvan refahı açısından da kuzu kayıplarının kabul edilemez bir durum olduğu dikkate alınmalıdır. Kuzu ölümlerinden kaynaklanan üretim kayıpları koyunculuk işletmelerinde üreme kapsamında ortaya çıkan maliyetin önemli bir kısmını oluşturmaktadır. Bu konuyla ilgili olarak koyunlarda kuzu verimi gebelik tarama sonuçlarına göre sütten kesim değerleri ile karşılaştırıldığında bu dönemde canlı kalan kuzu verimi yaklaşık \% 30 olarak tahmin edilmiştir (Hinch ve Brien, 2014). Birçok koyun 
1rkı üzerinde üreme performansına yönelik sürekli yeni teknikler ile iyileştirmeler yapılmasına rağmen, yavruların hayatta kalma oranları noktasında geçen yıllar içinde çok yavaş bir gelişim gerçekleşmiştir (Dwyer ve ark., 2016).

Kuzular vücutlarında onları hastalıklardan koruyacak antikorlar olmadan doğarlar ancak antikor içeriği zengin kolostrum alındıktan sonra enfeksiyonlara karşı bir korunmaya sahip olmaktadırlar (Anonim, 2004). Ayrıca yeni doğan kuzuların enerji rezervleri sınırlıdır ve vücudun normal sıcaklığını korumak ve hayatta kalmak için kolostruma hızlı erişme ihtiyacı vardır. $\mathrm{Bu}$ nedenle memeye erken erişmek yeni doğan yavru için esastır (Nowak ve Poindron, 2006).

\section{Kuzu Ölümlerinin Dönemsel Dağılımları}

Kuzularda en yoğun ölüm embriyonal dönemde olmakta ve bu değer \% 20-25'e kadar çıkabilmektedir. Bu ölümler yetiştirici tarafindan fark edilemez ve embriyonal ölümlerde ölen embriyo vücut tarafindan rezorbe edilir. Daha sonra koyun tekrar koç alabilir. Fetal dönem ölümleri ise daha azdır ve bu \% 3-5 arasında değişir. Bu tip ölümler yetiştiriciler tarafından erken doğum olarak tanımlanır. Perinatal periyod ölümlerinin hangi sınırda başladığ konusunda kesin bir tanım yoktur. Ancak doğumdan kısa bir süre önce olan ölümlerle doğum sonrası ilk hafta içindeki ölümler perinatal periyod ölümleri olarak tanımlanır. $\mathrm{Bu}$ dönemde görülen ölümler en yüksek düzeydedir. Postnatal periyot ölümleri, perinatal dönem sonundan sütten kesime kadar olan devredeki ölümlerdir (Şekil 1).

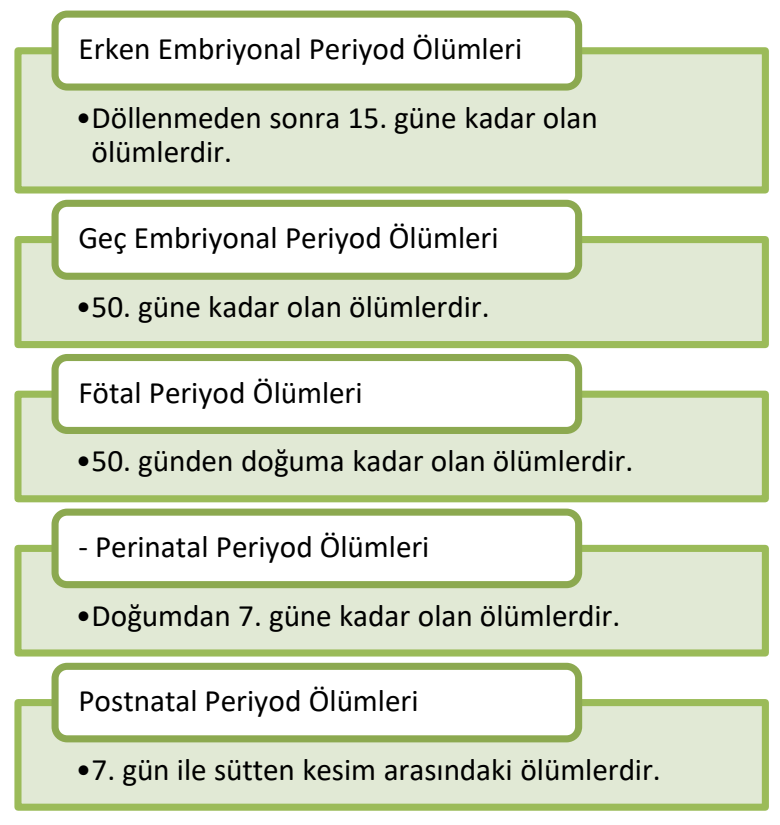

Şekil 1. Kuzu ölümlerinin dönemsel dağılımları
Bu süre 6 hafta ile 4 ay arasında değişir. Bu dönemdeki ölümlerde daha çok çevre faktörleri etkilidir. Yetiştirme şekli, nem, sıcak ve soğuk hava, besleme önemli çevre faktörlerindendir (Sarıcan, 2012).

\section{Kuzularda Yaşama Gücüne Etkili Olan Faktörler}

Bir kuzuyu doğumdan sütten kesime kadar ki yaşatma başarısı, fizyoloji, davranış, genetik, gebeliğin sonu kuzulama dönemi beslenme ve mevcut çevre koşulları gibi bir seri karmaşık bileşkenin sonucudur (Hatcher ve ark., 2010). Kuzu kayıplarının önemli bir kısmı yaşamın ilk 48 saatinde görülür (Brien ve ark., 2009) ve bunların büyük çoğunluğunda zor doğum, ananın kaybedilmesi ve açlığa maruz kalma gibi noktalar öne çıkmaktadır (Nowak ve Poindron 2006; Geenty ve ark., 2014). Doğum esnası ve hemen sonrasındaki ölümler annenin kaybedilmesine atfedilebilir, özellikle ilk defa doğum yapanlarda bu olayın çok daha sık rastlandığ edilmektedir (Hinch ve Brien, 2014).

Koyun ırkları arasında sütten kesme dönemindeki başarıda önemli farklılıklar, genetik yapının önemini ortaya koymakta ve sütten kesim döneminde hayatta kalmanın tahmini kalıtım derecesinin düşük olduğu ifade edilmektedir (Safari ve ark., 2007; Brien ve ark., 2014; Everett-Hincks ve ark., 2014). Bu özelliğin çok faktörlü bileşeninde çevresel ve özellikle de yönetim faktörlerinin önemi vurgulamaktadır.

\section{Doğum ăğtlı̆g}

Kuzularda yaşama gücüne etkili olan faktörler olarak kuzunun doğum ağırlığı, doğum tipi, cinsiyet, ananın beslenmesi ve yaşı öncelikli olarak sıralanır (Hatcher ve ark., 2009). Bunlar içinde doğumu takip eden ilk birkaç günde yaşama gücü üzerinde en fazla etkisi olan kuzunun doğum ağırlığıdır (Şekil 2). Kuzu ölümlerinin önemli bir kısmı doğumdan sonraki ilk günlerde yoğunlaşır ve bu da genellikle doğum ağırlığı ile ilişkilendirilmektedir (Nowak ve Poindron, 2006). İdeal doğum ağırlığı aralığı, ırklar arasında farklılık göstermekle birlikte $3.5-6.0 \mathrm{~kg}$ arasında değişmekte olup, ortalama 4.5 kg'da doğan kuzuların maksimum yaşama gücüne sahip olduğu belirtilmektedir (Oldham ve ark., 2011). Reshauge ve ark., (2015)'e göre düşük doğum ağırlığında doğan kuzuların aç kalmaya bağlı sorunlardan dolayı ölü doğma ihtimalinin yüksek olduğu bildirmişlerdir. Doğum ağırlığg 1.7 kg'ın altında olan kuzularda ölüm oranı \% 94'e çıkarken, ortalama 3.4 $\mathrm{kg}$ doğum ağırlığına sahip kuzularda bu değer \% 8.1'e inmektedir (Maud ve Duffell, 1977). Düşük canlı ağırlıkta doğan kuzular, vücut büyüklüğü ve enerji rezervleri ile ilişkili daha zayıf ısı düzenleme yeteneğine sahiptirler. Bu tip kuzularda gebeliğin son döneminde oksijen ve 
enerjinin yetersiz olması ile ilişkili olarak gelişimleri yavaşlamaktadır. Daha büyük kuzular ise pelvis kemiği ile orantısızlığa bağlı zor doğum ve doğumla ilişkili yaralanmaya daha yatkın olmaktadırlar (Hinch ve Brien 2014). Everett-Hincks ve Dodds (2008) tarafindan ifade edildiği gibi optimum doğum ağırlığının ortalamanın 0.5$1.0 \mathrm{~kg}$ üzerinde olan kuzlarda açlığa bağlı ölüm riskinin düşük, zor doğum olgunun daha az ve kuzularda yaşama gücünün daha yüksek olduğu ifade edilmektedir. Daha ağır doğum ağırlığına sahip kuzularında azalan yaşama gücü, zor doğum ve doğumun uzun sürmesinin direkt bir sonucudur (Dwyer, 2003).

Gebeliğin ilk 70 gününde özellikle kuzuların gebelik boyunca beslenmesini belirleyecek olan plasental büyüme gerçekleşmektedir. Bu periyodda uygulanacak yetersiz veya kısıtlı beslenme daha küçük kuzulara hatta fötal ölümlere neden olmaktadır (Anonim, 2017a).

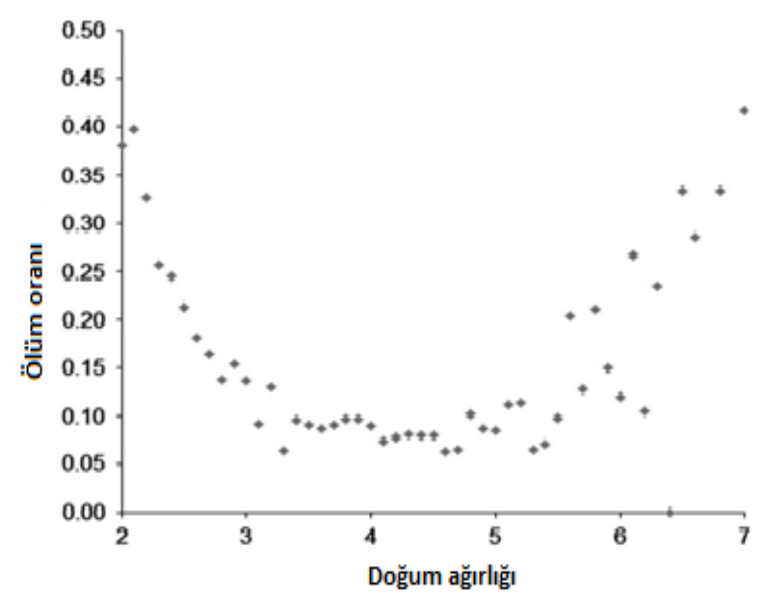

Şekil 2. İskoç siyah yüzlü kuzuları için ölüm oranı (\%) ve doğum ağırlığı (kg) arasındaki ilişki (Dwyer ve ark.,2016)

\section{Doğum tipi ve cinsiyet}

Doğum tipinin tek başına kuzularda doğum ağırlığı üzerine önemli bir etkisi vardır (Gardner ve ark., 2007). Doğum tipi, kuzularda yaşama gücünü özellikle de ikiz kuzu kayıplarıyla önemli oranda etkiler. Aynı sürüdeki kuzularda ikiz kuzu kayıpları, tekiz doğanlara göre genellikle 2-2.5 kat daha fazla olabilmektedir (Hinch ve Brien 2014). İkiz kuzularda ölüm nedenleri olarak açlık veya doğum sırasında yaralanma öne çıkarken, tekiz kuzularda ise ölü doğum veya zor doğum kaynaklı kayiplar daha yüksek gerçekleşmektedir (Refshauge ve ark.,2016). Dutra ve Banchero (2011) tarafindan doğumun tamamlanma sürecinde, özellikle çoğuz yavrulu gebeliklerde uzun sürmesinin sonucunda ortaya çıkan boğulma vakalarının kuzu yaşama gücüne önemli etkisi olduğu ifade edilmektedir.
Doğumdan sütten kesime kadar kuzu ölümlerinin önemli bir kısmı çoğuz doğan kuzularda görülmektedir. Yapılan çalışmalar göstermiştir ki, tek doğan kuzularda ölüm oranları \% 6-30 arasında değişirken, ikiz doğanlarda bu kayıplar aynı sürüler için bu değerin yaklaşık iki katı düzeyinde gerçekleşmektedir (Hatcher ve ark., 2009). Çoğuz doğan kuzlarda yaşama gücünün düşük olmasına neden olan faktörler doğum güçlükleri, düşük doğum ağırlı̆̆ı, doğum pozisyonu, büyük yüzey alanına bağlı 1s1 kaybı, vücut yağ rezervlerinin az olması, diğer kardeşi ile kolostrum ve süt içme rekabeti, ananın sütünün yetersiz olması olarak sıralanmaktadır (Hatcher ve ark., 2010).

Kuzunun cinsiyeti de yaşama gücünü etkiler. Dişi kuzuların hayatta kalma oranları erkek kuzuların 1.3 katıdır ve ayağa kalkma ve emme için daha az zaman harcarlar.

\section{Koç ve koyun seçimi}

Kuzuların yaşama gücü koyun ve koç faktörleri ile de ilişkilidir. Bir yıl kuzu üretmeyen koyunların takip eden y1llarda kuzu kaybetme ihtimalinin daha yüksek olduğu ifade edilmektedir (Hatcher ve ark., 2009). İdeal doğum ağırlığına sahip kuzular üretmek, yeterli kolostruma sahip olmak ve erken emzirme döneminde süt verimini koruyabilmek için, bir koyun aşırı kondisyonda olmamak kaydı ile doğum döneminde yeterli vücut rezervine sahip olması gerekir. Vücut kondisyon skorlaması, koyunların vücut rezervlerini ölçmek için kullanışlı bir tekniktir. İdeal olarak, koyunlar aşım ile kuzulama arasında yarıdan fazla bir kondisyon skoru kaybetmemelidir. Özellikle gebeliğin ilk haftasında kondisyon değişikliklerinden kaçınılmalıdır. $\mathrm{Bu}$ süre zarfinda, embriyolar, koyunlarda beslenme bozukluğuna karşı oldukça savunmasızdır. Eğer koyunlarda bir kondisyon değişikliği gerçekleşirse, verilen yem miktar ve içeriğinin değiştirilmesi yoluna gidilebilir.

Koçlar, direkt olarak kuzuların davranışına, indirekt olarak ise plasental gelişmeyi etkileyerek fetüsün fizyolojisini etki yapmaktadır. $\mathrm{Bu}$ farklllıklar kuzu yaşama gücünün saptandığı Merinos ırkındaki farklı sürülerde (Hergenhan ver ark., 2014) ve farklı çevre koşullarında bulundurulan irklar arasında gözlenmiştir (Dwyer ve Lawrence, 2005). Analık yeteneği ve kuzu yaşama gücü $1 \mathrm{rk}$ içinde düşük varyasyon ve kalıtım derecesi gösterirken, irklar arasında ise heterosisten kaynaklanan yüksek bir varyasyona sahiptir (Brien ve ark., 2014). 


\section{Koyunların beslenmesi}

Ana karnında fetüsün ve yeni doğan kuzuların doğru gelişimi, besinlerin plasenta ve meme bezine yeterince taşınmasını gerektirir. Gelişmekte olan bir fetüsün doğum ağırlığının yaklaşık üçte ikisi gebeliğin son altı haftasında kazanılır. $\mathrm{Bu}$ nedenle, gebeliğin son dönemindeki dengeli beslenme fetal gelişim ve doğumda yaşama gücü açısından çok önemlidir. Gebe koyunların gelişimini, embriyonik ve fetal büyümeyi, metabolik süreçlerin devamını, meme bezi büyümesini, kolostrum ve süt verimini etkileyen enerji ve protein rasyonda yeterince bulunmalıdır. Besin maddelerinin yeterli miktarda dokulara taşınması aynı zamanda fetal ovaryum gelişimi, postnatal büyüme, üreme performansı ve metabolizmayı da etkiler (Mahoub ve ark., 2013).

Gebelikten doğuma kadar koyunların beslenmesi, kuzuların sağlığı ve yaşama gücü için önemli bir faktör olarak bilinmektedir (Kleemann ve ark., 1993; Brien ve ark., 2014; Hinch ve Brien 2014; Rooke ve ark., 2015). Koyunların beslenmesi direkt olarak doğum ağırlığını, süt miktarını, ana-yavru bağının kurulmasını, doğum sonrası kuzu büyümesini ve koyun ölümlerini etkilemektedir (Trompf, 2014). Gebeliğin son üçte birinde ananın yetersiz beslenmesinin kritik bir önem taşıdığı, kuzu doğum ağırlığı ve sütten kesime kadarki yaşama gücünde annenin yetersiz beslenmesinin \%50-85 oranında etkili olduğu ifade edilmektedir Rooke ve ark., (2015). Yapılan bir çalışmada, gebelikte yem kısıtlamasının İskoçya Blackface koyunlarında doğumdan sonraki dönemde ana davranışlarında bir zayıflamaya neden olduğu saptanmıştır (Dwyer ve ark., 2003). Diğer taraftan yetersiz beslemenin koyunlarda analık davranışı üzerine yaptığı etki, yavrularda yaşama gücünü etkileyebilir (Dwyer ve ark., 2010).

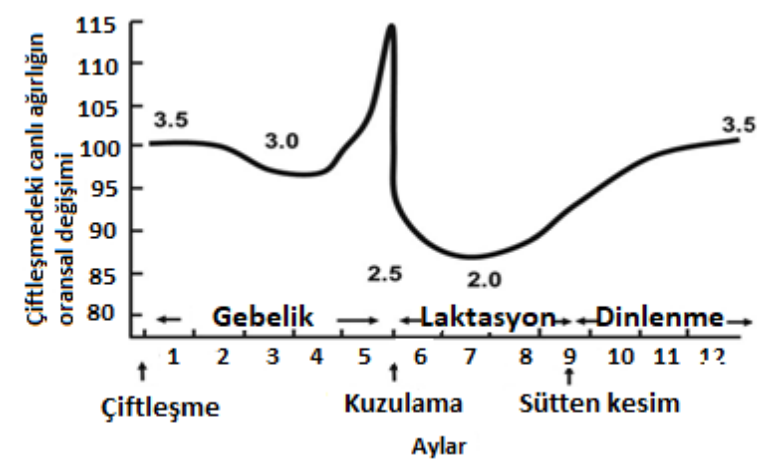

Şekil 3. Üreme döngüsü boyunca koyunlarda canlı ağırlık değişimi, eğri üzerinde verilen değerler ortalama vücut kondisyon skorlarıdır (Dwyer ve ark.,2016)
Özellikle ikiz doğan yavrularda ananın vücut kondisyonunun dikkatli takibi yavru kayıplarını en aza indirmede hayati önem taşıdığı ifade edilmektedir (Everett-Hincks ve Dodds, 2008). Vücut kondisyon skoru koyunların ekstra beslemeye gerek olup olmadığını belirlemede çok yararlıdır (Şekil 3). Vücut kondisyon skorunun bu dönemde 2.0 ile 3.0 arasinda olmas1 gerektiği belirtilmektedir (Kenyon ve ark., 2012). Aynı zamanda, rasyonda enerjinin aşırı verilmesine bağlı artan doğum ağırlıkları zor doğum ve buna bağlı doğum travmasına neden olabilmektedir. Bu evrede yapılacak yetersiz beslenme gebelik zehirlenmesi, fetal ve neonatal ölümlere ve düşük kaliteli kolostruma neden olmaktadır. Eğer gerekli ise bu dönemde iz elementler ve ek mineraller verilmelidir. Gebelikte en fazla görülen vitamin E ve selenyum eksiliğidir. Gebelik boyunca koyunlara verilen ek minerallerin sağlığı koruduğu ve kuzularda yaşama gücünü artırdığı kanıtlanmıştır (Dwyer ve ark.,2016). Fetüs gelişimi için kuzulama öncesindeki son 2-3 hafta boyunca yeterli protein sağlanması hayati önem taşır.

Koyunun yetersiz beslenmesinin diğer yan etkileri ise, meme gelişiminde gerilemenin yanı sıra kolostrum üretimi ve kalitesinde azalma olarak görülür. Orta veya geç gebelik dönemindeki besleme takviyesi, kuzu doğum ağırlığı, kolostrum ve süt üretimini artırarak kuzu ölümlerini azaltmak için kullanılabilir. Ayrıca koyunların gebelik süresi boyunca beslenmesi doğumda analık davranışlarını da etkilemektedir. Yetersiz beslenmiş koyunlar kuzularıyla etkileşim kurmaları daha fazla zaman alırken, daha fazla saldırganlık göstermekte, kuzularını yalamak için daha az zaman ayırırmakta ve doğumdan sonra beslenmek için daha fazla zaman geçirmektedirler (Nowak ve Poindron, 2006).

Aşım dönemi koyunların beslenmesinin kuzu fizyoloji ve davranışımı da etkilediği belirtilmektedir (Kleemann ve ark., 2015), koyunların tohumlandığı dönemde yetersiz beslendiklerinde daha küçük ve az hareketli kuzu doğurdukları ifade edilmektedir.

\section{Ana-yavru bağının kurulması}

Yavrular açısından doğumdan sonra anne dışındaki bir hayata geçiş karmaşık bir süreç oluşturmaktadır (Şekil 4). İdeal koşullar altında, koyun yeni doğan kuzularıyla seçici bir bağ oluşturur. Bu koyun ve kuzusu arasındaki çok ince ve hassas dengelerde ayarlanmış bir değişimi içerir. (Dwyer ve Lawrence, 1999). Özellikle doğumun uzun sürmesi koyunların kuzularına olan ilgi ve bakım istekliliğini etkileyebilmektedir (Dwyer ve ark., 2003). 
$\mathrm{Bu}$ nedenle zor doğuma yol açan faktörler muhtemelen ana-yavru ilişkisini de etkileyecektir. Doğumdan hemen sonra hem kuzu hem de koyun birbirlerini tanımayı öğrenmek zorundadır ve özellikle emzirme ve iletişime dayanan faaliyetleri başlatmaktan yalnızca kuzu sorumludur. Doğum sonrası ilk saatler, kuzu için anasına bağlanmanın kritik bir zaman dilimidir (Poindron ve ark.,
2007). Bu nedenle, iletişim faaliyetini olumsuz etkileyen faktörler, bağlanma sürecini de aksatabilecektir. Bu aşamadaki anormal davranış veya diş etkenler, özellikle de ikiz doğum yapan koyunlarda yavrularından ayrılmalarına ve kuzuların ölümüne yol açabilir. Bu bağın doğru şekilde oluşturulması, doğum yerinde veya yakınında harcanan zamana bağlıdır.

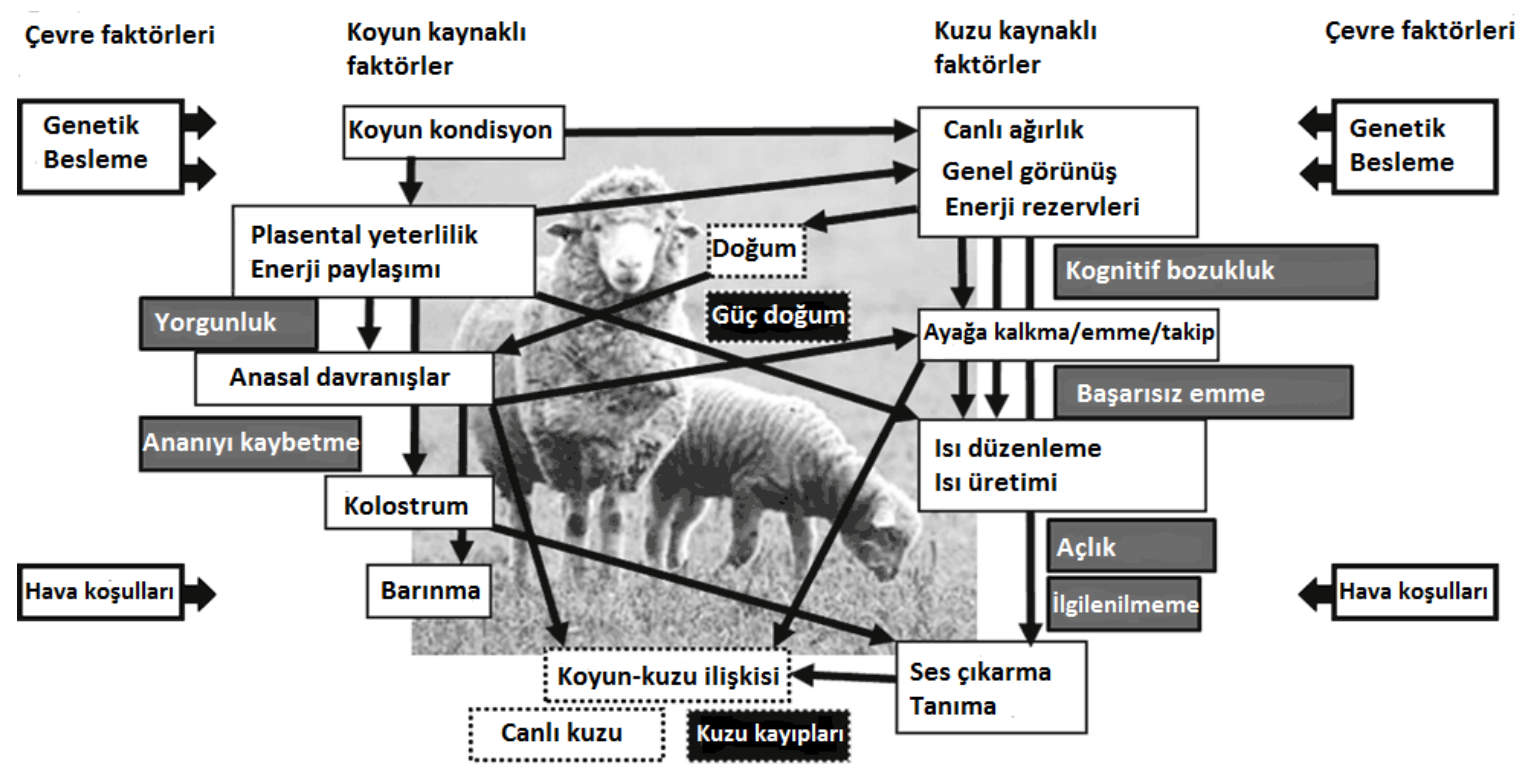

Şekil 4. Kuzularda yaşama gücünü etkileyen faktörler. Koyun kaynaklı faktörler "sol", kuzu kaynaklı faktörler "sağ" kısımda belirtilmiştir. Fizyolojik faktörler beyaz zemin üzerine siyahtır. Kuzu kaybına neden olanlar gri üzerine beyazdır. Çıktılar noktalı çizgiye sahiptir (Dwyer ve Lawrence, 1999)

Doğumdan sonra doğum yerini çok kısa sürede terk ederek aralarında yetersiz bağ oluşan ana ve yavrularda daha fazla ayrılma olasılığı ve ölüm görülebilmektedir (Nowak ve Poindron, 2006). Doğumdan sonraki dönemde ana ile kuzusu arasındaki bağın kuvvetli bir şekilde kurulmamasından kaynaklanan oldukça yüksek düzeylerde kuzu kayıpları (\%9) görülebilmektedir. $\mathrm{Bu}$ nedenle doğum sonrası ilk 24-36 saat içerisinde ana ile kuzu arasında güçlü bir bağın kurulması, kuzu ölümlerinin azaltılması açısından önem taşımaktadır (Çam ve ark., 1997; Özdemir ve Altın, 2007). İdeal olarak, koyunlar ve kuzuları arasında kuvvetli bir bağ ve kuzuların hayatta kalma şanslarını optimize etmek için koyunlar doğumdan sonra en az 6 saat boyunca doğum yerinde kalmalıdır. Koyunların birçoğu, doğum yerini hızlı bir şekilde yiyecek ve su bulmak için terk eder. Bu davranışı insanlar, köpekler ve sinirlilikten kaynaklanan rahatsızlıklar sonucunda da hızlandırabilmektedir. Kuzulama öncesi ve sırasında bölmede kaba ve kesif yem bulunması koyunun doğum sonrası kuzusu ile ilgilenmesi ve emzirmesini kolaylaştırır, koyun-kuzu ilişkisini güçlendirir (Dwyer, 2003). Seyrek mera örtüsünden kaynaklanan açlık ve doğum sırasındaki kötü dış koşullar onları doğum bölgesini terk etme ve diğer doğuran koyunları etkilenme ihtimalini artırabilir.

Analık davranışı kuzuyu yoğun olarak yalama, meleme ve doğumu takip eden ilk 6 saat emmesi için ayakta durma şeklinde karakterize edilebilir ki emme davranışı kuzu tarafından tanınma ve koyun-kuzu arasındaki bağı oluşturmayı kolaylaştırır (Goursaud ve Nowak 1999). Ananın yavruyu yalaması sadece k1llar1 kurutmaz, kuzuyu temizler ve uyarır. Aynı zamanda yavrunun kokusunun farkına vararak güçlü bir bağ oluşmasını kolaylaştırır. Tekiz doğuran koyunlarda kuzularını yalamaya başlamaları çoğuz doğuran koyunlara göre daha yavaş olmaktadır. Tek doğuran veya güç doğum yapan koyunlarda bu davranış gecikebilir. Birden fazla yavru doğuran koyun ikinci kuzu doğduğunda ilk doğan kuzuya olan ilgisini kaybedebilmektedir. Çoğuz doğum yapan koyunun birden fazla kuzuyu yalayarak kurutması daha uzun sürdügünden, olumsuz koşullarda 
hipotermiye yakalanma riski artar (Nowak ve Poindron, 2006). Kuzunun yoğun bir şekilde yalanması, düşük perdeli meleme ile karakterizedir ve ilk 6 saat içindeki emme ile devam eder. Bu da kuzu tarafindan emmeyi, tanımayı ve koyun-kuzu bağını oluşturmayı kolaylaştırır. (Goursaud ve Nowak 1999). Bireysel olarak analık davranışı arasında farklı1ıklar görülebilir ki özellikle deneyimli koyunların analık davranışları daha güçlüdür. En erken analık davranışının göstergesi doğum yerinde harcanan zaman olup bu birçok trk için 6 saat olsa da (Ison, 2016), Avustralya Merinos koyunlarında 1.33.5 saat arasında değiştiği belirtilmektedir (Hergenhan ve ark., 2014). Bununla birlikte, analar ilk kuzulamalarının sonrasında analık tecrübesi kazandığından sonraki gebeliklerde daha iyi annelik yaklaşımı göstermektedirler (Nowak ve Poindron, 2006).

\section{Memenin bulunmast ve ana ayrım yeteneği}

Kuzular düşük enerji rezervi ile doğduklarından, mümkün olan en kısa sürede memeyi bulmaları ve kolostruma ulaşmaları çok önemlidir. Kuzuların birçoğu doğumdan sonraki ilk 2 saat içinde emmeye bașlar, ancak kuzuların bu davranışları ırklar arasında önemli farkl1lıklar gösterebilmektedir. Analık içgüdüsü, doğum ağırlığı, cinsiyet ve doğum tipi de kuzuların ayakta kalma ve meme bulma sürelerini etkileyebilmektedir. Bu davranış yönünden erkek kuzuların genellikle dişilerden ve ikiz doğan kuzuların tekiz doğanlardan daha yavaş oldukları belirtilmektedir. Doğumdan hemen sonra kuzu, vücut ısısını düzenleyebilme, ayağa kalkabilme, memeyi bulma, emme ve anasinı takip etme refleksine sahiptir.

Koyunlar doğumdan sonraki saatler içinde doğum yerinden uzaklaşırlar. Yeni doğanlar için, saatlik emzirmeye ihtiyaç duyduklarından, kolostrum kaynağının yakınında kalması en iyi hayatta kalma stratejisidir. Genellikle kuzular doğumundan sonraki ilk 12-24 saat içinde öz anası ile yabancı bir ana arasında ayrım yapabilir ve bu yeteneği doğumdan sonraki ilk birkaç gün boyunca belirgin bir şekilde geliştirir. İkiz doğanlarda bu zaman dilimi biraz daha uzayabilmektedir. Emzirme, doğumdan sonraki ilk birkaç saat boyunca engellendiğinde, kuzuların ayırt etme kabiliyeti, 24-48 saat arasında kaybolmaktadır. Yeni doğan kuzularda uzun emzirme dönemi önlenir ise ana için tercih gelişmesi o kadar uzun sürer (Nowak ve Poindron, 2006).

\section{Ana yaşı}

Ana yaşının kuzu ölümleri üzerine etkisi bulunmaktadır. Genç koyunlar düşük doğum ağırlıklı kuzu doğurduklarından yaşlı koyunlara göre doğum esnasında daha az yardıma ihtiyaç duyarlar. Genç analar yaşlı olanlara göre daha zayıf analık davranışı gösterirler ve doğum sonrası yavrularını yalama davranışı daha yavaştır. Yaşlı koyunlarda meme problemleri görülme riskinin yüksek olmas1, yavrularının yaşama gücünü olumsuz etkiler (Hatcher ve ark., 2010).

\section{Doğum yeri seçimi ve izolasyon}

Yeni doğan kuzunun erken gelişimi ve hayatta kalması tamamen annasının sağladığı bakıma bağlıdır. Koyunlarda doğumun yaklaşmasıyla kendilerini sürüden ayırma eğilimi başlar. Entansif yönetim sisteminde eğer gebe koyuna ayrı bir bölme verildiyse kuzulama öncesinde kendini izole etmeyi tercih etmektedir. Ekstansif koşullar altında doğum yapan koyunda aktif olarak bir izolasyon arayış1 görülmez. Çoğu durumda doğumun kesin yeri, fetal sıvıların ilk önce döküldüğ̈̈ yere göre belirlenir. Sosyal hareketlilikteki bu değişim, doğum öncesi diğer koyunların müdahale riskini en aza indirirken, tatmin edici ana-yavru ilişkileri kurulmasını sağlar. Nitekim ana-yavru arasında bağ kurulmasında yaşanan en büyük rahatsızlık kuzulama sırasında ortamda bulunan diğer gebe koyunlardır (Nowak ve Poindron, 2006).

Barınaklar, kuzulamanın stresli olduğu süreçte hem koyunu hem de çobanı korur. Sağlanan koruma kuzu kayıplarını azaltma eğilimindeyse de, barınakların başka problemleri beraberinde getirebileceğini bilmek önemlidir. $\mathrm{Bu}$ risklerin ilki kuzuların bulaşıcı hastalıkların yayılmasına neden olan koşullara maruz kalma riski artar. İkinci olarak ise anasız kuzu artışına neden olur (Anonim, 2004).

\section{Kuzuların enerji rezervleri ve çevre koşullart}

Doğumdan sonraki ilk birkaç saat, sıcak rahim çevresinden diş dünyaya geçişten kaynaklanan büyük 1s1 kaybına karşı koymak, kuzunun hayatta kalması için kritik önem taşır. Herhangi bir kolostrum alınmadan vücut sıcaklığını korumak için, kuzu kahverengi yağ dokusu enerji rezervlerini metabolize etmekte ve titreme ile kas aktivitesini arttırmaktadır. Küçük kuzuların ve gebelik sırasında yetersiz beslenmiş olan koyunlardan doğan kuzuların yăg 
rezervleri orantısız olarak düşüktür ve dolayısıyla hayatta kalma şansları daha azdır. Özellikle enerji rezervlerinin miktarı, hava koşulları olumsuz olduğu noktada hayatta kalmak için ilk kritik koşuldur. Enerji rezervleri, herhangi bir kolostrum alımı olmaksızın kuzunun hayatta kalabilmesi açısından önemlidir. Ancak yeni doğan kuzunun sert hava koşullarına direnebileceği süreyi sınırlayan başlıca faktör yağ değil, mevcut karbonhidrattır. Kötü hava koşulları veya sonrasında gözlenen yüksek ölüm oranı, vücuttaki yă̆ rezervlerinin tükenmesinden daha öncelikli olan hipotermi ve hipogliseminin bir sonucudur. Tek başına rüzgar hızı bile, ısı kaybına ve sonucunda kuzu ölümlerini artıran çok önemli bir unsur olarak vurgulanmıştır. Isı kaybı ağırlıklı olarak yüzey alanına bağlı iken, 1sı üretimi vücut ağırlığına bağlıdır. Dolayısıyla küçük kuzular hipotermiye büyük kuzulara göre daha yatkınlardır (Nowak ve Poindron, 2006).

\section{Ist Stresi}

Yeni doğan kuzularda 1sı stresi soğuğa maruz kalma, rüzgar hızı, ortam sıcaklığı ve yağışın bir fonksiyonu olarak ortaya çıkmaktadır Küçük kuzular boyutlarına ve enerji rezervlerine göre termoregülatör yetenekleri zayıftır, bu da onları soğuğa karşı daha fazla hassas yapar (Şekil 5). Bununla birlikte, rüzgar hızındaki bölgesel farklılıklar barınakların yapısal özelliklerine göre farklı sonuçlar doğurabilir. $\mathrm{Bu}$ da bölgelere özgü hava koşullarına göre barınak yapılmasını zorunlu kılmaktadır. Erken ayağa kalkan ve emen kuzuların daha fazla 1sı üretebildikleri ve soğuğa maruz kalma sonucu ölme olasılığının daha düşük olduğu gözlenmiştir (Hergenhan ve ark., 2014). Soğuğa maruz kalmaya karşı direnç, aynı zamanda kuzu cinsiyeti ve baba irkına özgü özellikle post kalınlığı ve yapağı sıkılığı ile de ilişkilendirilebilir, ancak bu noktada elde edilen sonuçlar paralellik göstermemektedir (Oldham ve ark., 2011; Ison, 2016).

Sıcaklık ölçümü

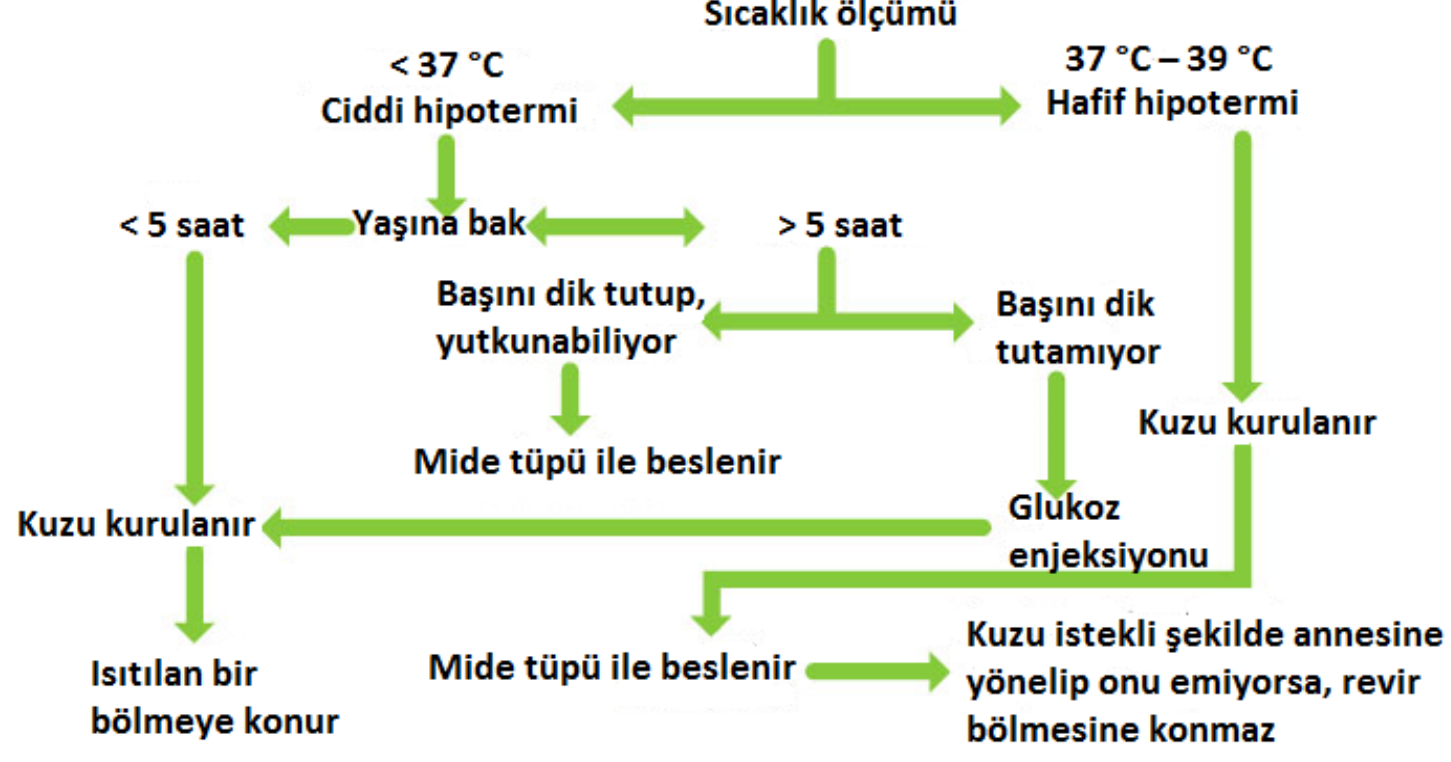

Şekil 5. Kuzu yaşama gücü şeması (Anonim 2017b)

\section{Yeterli kolostrum alımı}

Kuzulamaya kadar doğru beslenme, kolostrum üretimine etki eder. Koyunların otlatılması yüksek nişasta taneleri ile desteklenmesi, yeni doğan kuzu için mevcut olan kolostrum miktarını iki katına çıkarabilir (Banchero ve ark., 2015). İkiz yavruya gebe koyunlar genellikle tekiz yavruya gebe koyunlara göre daha fazla kolostrum üretirler, ancak bu kuzu başına fazla miktarda kolostrum ürettikleri anlamına gelmez ki bu da ikizler için ciddi sonuçlar doğurur. Mc Neill ve ark., (1988)'nın Merinos koyunlarında yaptığı çalışmada, ikiz yavruya gebe koyunların \% 30'unun doğumdan sonra yetersiz kolostruma sahip olduğu, tekiz doğuran koyunların ise yaklaşı \% \% 10'un da kuzu için yetersiz kolostrum ürettiğini belirtmişlerdir.

Doğum öncesi anaların ihtiyacının karşılanması yeterli ve kaliteli kolostrum üretimi açısından da 
önemlidir (Banchero ve ark., 2004). İkiz yavru taşıyan koyunlarda laktasyonun başlaması gecikebilir, bu nedenle İkiz yavruya gebe koyunlarda enerji kullanılabilirliğinin artması önem taşımaktadır. Özellikle ikiz kuzularda kolostrum hacmi ve yoğunluğunu emme davranışını etkileyebilir (Holst ve ark., 1996). Bu da koyun-kuzu yakınlaşması ve kuzuya enerji sağlanması noktasında öne çıkmaktadır.

Kolostrumun önemi, kendi bağışıklık sistemi korumasının tamamen işlevsel hale gelmeden gerekli antikorları anneden yavruya aktarmaktır. Koyun gibi epitelyokoryal plasenta yapısına sahip olan türler için immünoglobulinler plasenta bariyerini geçmediğinden immünoglobülinlerin ananın kolostrumundan transferi işlemi kuzunun yaşama gücü için büyük önem taşır. Bir kez emme sağlandığında, serum immünoglobülinleri ilk bir saatte hızla yükselir ve doğumdan yaklaşık 24 saat sonra zirve yapar. Düşük kolostrum verimi veya düşük meme arama etkinliği nedeniyle kuzu tarafindan emmede herhangi bir gecikme, patojen enfeksiyona karşı korunacak yeterli immünoglobülin elde etme şansını azaltır (Nowak ve Poindron, 2006).

Kolostrum kuzular tarafindan zamanında ve yeterince alınması ölüm oranını azaltmada en etkili ve en ucuz yoldur. Bu kapsamda kolostrumun doğumdan sonraki ilk 18 saat içerisinde alınması gerekliliği ve bu süre içerisinde yavrunun bağırsak yapısı, kolostrum molekülünü absorbe edecek çapa sahip olduğu unutulmamalıdır. Bir kuzu yetersiz kolostrum aldığında isal, pnömoni ve menenjit gibi sağlık sorunları ile karşılaşma olasıllğı artar. Yetersiz kolostrum alımı ile ilişkili en yaygın hastalık E.coli (sulu ağız) dır. E. coli çevresel bir patojendir, doğumu takip eden ilk 12 saatinde kuzunun bağırsağında çoğalır, kaliteli kolostrumun varlığı hastalığın oluşumunu engeller (Anonim, 2017a). E. coli yaygın olduğu durumlarda oral antibiyotiklerle önleyici tedavi, hastalığa bağlı ölümleri azaltmada çok başarılı olabilir. Doğum sonrası gerekli olduğu koşullarda meme başındaki keratin yapının bakıcının müdahalesiyle uzaklaştırılması ile kuzular kolaylıkla kolostrumu alabilme olanağı sağlayacaktır. Kuzunun yeterli kolostrum almadığından şüphe edildiği durumlarda muhakkak anası ve başka bir ananın kolostrumu mide tüpü ile kuzuya verilmelidir. İyi bir kolostrum yönetimi, ölüm oranını azaltmada en etkili ve ucuz araçtır. Kuzular canlı ağırlıklarına göre farklı miktarda süt içerler. Doğal koşullar altında, bir kuzu, gün boyunca anasından onlarca kez küçük miktarlarda süt alma eğilimindedir. $\mathrm{Bu}$ nedenle, kuzulara günlük ihtiyacını belli aralıklarla vermek özellikle sindirim problemlerini önleme açısından da önemlidir (Çizelge 1).

\begin{tabular}{cccc}
\multicolumn{5}{c}{ Cizelge 1. Kuzulara süt içirme programı (Anonim, 2017c) } \\
\hline $\begin{array}{c}\text { Besleme dönemi } \\
\text { (gün) }\end{array}$ & $\begin{array}{c}\text { Her öğündeki } \\
\text { miktar (ml) }\end{array}$ & $\begin{array}{c}\text { Günlük besleme } \\
\text { sayıs1 (adet) }\end{array}$ & $\begin{array}{c}\text { Günlük alınan } \\
\text { süt miktar (ml) }\end{array}$ \\
\hline 1 (kolostrum) & 100 & 3 & 300 \\
$2-7$ & 150 & 5 & 750 \\
$8-14$ & 240 & 4 & 960 \\
$15-21$ & 330 & 4 & 1320 \\
$22-28$ & 440 & 3 & 1320 \\
29-sütten kesim & 475 & 2 & 950 \\
\hline
\end{tabular}

\section{Kuzu kayplart}

İşletmelerdeki doğum dönemi ve sonrasındaki kuzu kayıpları refah probleminin ve önemli bir ekonomik kaybın göstergesidir. Fazla sayıda kuzuyu yaşatabilme noktasında doğum dönemi için iyi bir planlama ve hazırlık, ihtiyacı karşılayacak doğum ve kuzu bölmeleri, tecrübeli işçiler, kuzulama döneminde gözetim iyi yapılması noktasında personel sayısının artırılması ve sorunlu kuzuların erken tanınması büyük önem taşımaktadır. Çoğu kuzu kayıpları doğum esnasında ortaya çıkar. Kuzu ölümünün başlıca nedenleri şunlardır: Hijyen ve göbek kordonu bakımı, abortus ve ölü doğumlar, öksüz kalma ve açlık, enfeksiyon hastalıklar, doğmasal kusurlar, yırtıcılar ve diğer etkenler (Çizelge 2).

Hijyen ve göbek kordonu bakımı: İşletmelerde hijyenin önemi hafife alınmamalıdır. Özellikle doğum dönemimde hem insan hem de hayvan sağlığı açısından daha da önemlisi kuzu kayıplarını azaltma noktasında oldukça önemlidir. Kirli ellerle yapılan doğuma yardım uterus enfeksiyonlarına, sağım 
mastitise neden olur. Kuzularda göbek kordonu doğumdan hemen sonra dezenfekte edilmelidir. Genellikle en çok kullanılan dezenfektan sprey veya daldırma yönetimiyle kullanılabilen \%10 tentürdiyottur (Anonim, 2017a). Diğer taraftan sürüler içinde ve sürüler arasındaki hastalık yayılımını önleme kapsamında temel karantina kurallarının uygulanmasını öne çıkaran çiftlik biyogüvenlik politikasının oluşturulması gerekmektedir.

Abortus ve ölü doğumlar: Uygun bir hastalık araştırması ve aşılama programı ile kayıpları azaltmak ve hastalıksız bir sürü olușturmak mümkündür. Özellikle bu noktada konu uzmanlarının tavsiyeleri doğrultusunda hareket etmek en doğrusudur.

Öksüz kalma ve açlı: Doğum döneminde sorunlu olan kuzuların beslenmelerine önem vererek, risk altındaki kuzuların erkenden tanınması ve doğru tedavisi, kuzu yaşama gücü oranını artıracaktır.
Enfeksiyon hastalıklar: Hijyen ve dezenfektanların doğru ve zamanında kullanımı yanında, hastalıklara yakalama riski doğru bir sağlik koruma programının izlenmesi ile başarılabilir. Doğumdan sonraki kuzu ölümlerinin en büyük etkeni patojen mikroorganizmalardır. Patolojik bulgulara dayanan ölüme neden olan enfeksiyöz hastalıklar (Pneumonia, Enteritis, Arthritis, Encephalitis, Myocarditis, Göbek kordonu enfeksiyonları, Peritoritis, Nephritis, Sternal ve spinalabzesse) olarak siralanmaktadır (Busse, 1981). En önemli ölüme yol açan hastalık Pneumonie'dir. Bu da ancak doğumdan 15 gün sonra görülmeye başlanır. Barsak ve işkembe ile ilgili hastalıkları kuzuların anasız büyütülmesinde daha sık görülür.

Yırtıcılar ve diğer etkenler: Zayıf ve öksüz kuzuların ayrı bir takibi yapılmadığı sürece vahşi hayvanlar ve diğer birçok neden ile kayıplar ortaya çıkacaktır.

Çizelge 2. Kuzu ölümlerinde etkili faktörler, ortaya çıkış nedenleri ve çözümler (Lambex, 2014)

\begin{tabular}{|c|c|c|}
\hline Kuzu ölümlerinde etkili faktörler & $\begin{array}{l}\text { Kuzu ölümlerinin temel } \\
\text { sebepleri }\end{array}$ & Etkili faktörlere ilişkin çözümler \\
\hline Düşük doğum ağırlığı & $\begin{array}{l}\text { Yetersiz beslenme } \\
\text { Barınak yetersizliği } \\
\text { Vahşi hayvan saldırısı }\end{array}$ & $\begin{array}{l}\text { Gebelikte beslenme(Özellikle ikiz gebelikte) } \\
\text { Korunaklı kuzu barındıran padoklar } \\
\text { tilki kontrol programları }\end{array}$ \\
\hline Ağır kuzulara bağlı güç doğum & Doğum stresi & $\begin{array}{l}\text { Gebelikte beslenme (Özellikle tekiz gebelikte) } \\
\text { Kuzulama sırasında bakıcı desteği } \\
\text { Genetik seleksiyon }\end{array}$ \\
\hline $\begin{array}{l}\text { Koyunlarda doğum sürecinin } \\
\text { tamamlanması için enerjinin } \\
\text { yetersizliği }\end{array}$ & $\begin{array}{l}\text { Doğum stresi } \\
\text { Yetersiz beslenme }\end{array}$ & $\begin{array}{l}\text { Gebelikte beslenme } \\
\text { Doğum yerinde yem bulundurulması }\end{array}$ \\
\hline Terk edilmiş/Anasız kuzu & $\begin{array}{l}\text { Yetersiz beslenme } \\
\text { Barınak yetersizliği } \\
\text { Vahşi hayvan saldırıları }\end{array}$ & $\begin{array}{l}\text { Koyunun kuzulama için uygun kondisyonda olması } \\
\text { Doğum yerinde yem bulundurulması } \\
\text { Daha iyi analık davranışları ile kuzu yetiştirilmesi } \\
\text { Kuzulamada sürü sıklığı ve yoğunluğu }\end{array}$ \\
\hline Yetersiz süt & Yetersiz beslenme & $\begin{array}{l}\text { Koyunun kuzulama için uygun kondisyonda olması } \\
\text { Doğum yerinde yem bulundurulması } \\
\text { Kolostrum miktarını artırmak için tane yemle } \\
\text { besleme }\end{array}$ \\
\hline Vahşi hayvanlar & Vahşi hayvan saldırıları & $\begin{array}{l}\text { Tilki kontrol programları, vahşi köpek toplulukları } \\
\text { için programlar }\end{array}$ \\
\hline Olumsuz hava koşulları & Barınak yetersizliği & $\begin{array}{l}\text { Korunaklı kuzu barınakları ve hakim rüzgarları } \\
\text { engelleyen uygun yükseklikte padoklar }\end{array}$ \\
\hline
\end{tabular}

\section{Kaynaklar}

Anonim 2017a. Care and welfare of the neonatal lamb, Scarsdale Vets Farm. http://www.csarsdalevets.com $(06.02 .2017)$

Anonim 2017b. Reducing lamb losses for better returns. http://www.beefandlamb.ahdb.org.uk (14.06.2017)

Anonim 2017c. Lamb \& Goat Kid Rearing Guide. http://www.veanavite.com.au/RearingGuide/LambsGo atKids.aspx (20.06.2017)
Banchero GE, Quinans G, Martin GB, Lindsay DR, Milton JTB 2004. Nutrition and colostrum production in sheep. 1. Metabolic and hormonal responses to high-energy supplement in the final stages of pregnancy. Reproduction, Fertility and Development, 16: 633-643.

Banchero GE, Milton JTB, Lindsay DR, Martin GB, Quintans G 2015. Colostrum production in ewes: a review of regulation mechanisms and of energy supply. Animal 9, 831-837. 
Brien F, Hebart ML, Hocking Edwards JE, Greeff JC, Hart KW, Refshauge G, Gaunt G, Behrendt R, Thomson K, Hinch G, Geenty KG, Van Der Werf JHJ 2009. Genetics of lamb survival: preliminary studies of the information nucleus flock. In 'Proceedings of the eighteenth conference: matching genetics and environment: a new look at an old topic', Barossa Valley, SA, 28 September - 1 October 2009. (Eds A Safari, B Pattie, A Restall) pp. 108-111.

Brien FD, Cloete SWP, Fogarty NM, Greeff JC, Hebart ML, Hiendleder S, Hocking Edwards JE, Kelly JM, Kind KL, Kleeman DO, Plush KL, Miller DR 2014. A review of genetic and epigenetic factors affecting lamb survival. Animal Production Science 54, 667-693.

Busse G 1981. Die Akivitöten von Citrazyklusenzymen und der Glutathion-Reduktase und Ihve Beziehungen zur überlebenföhigkeit des Lammes in der perinatalen Phose. Diss. Giessen.

Çam MA, Kuran M, Selçuk E 1997. Koyun yetiştiriciliğinde ana-yavru ilişkileri ve önemi. Turkish Journal of Veterinary and Animal Sciences 23 (2): 335 341.

Dutra F, Banchero G 2011. Polwarth and Texel ewe parturition duration and its association with lamb birth asphyxia. Journal of Animal Science ,89 (10): 3069-78.

Dwyer CM, Lawrence AB 1999. Does the behaviour of the neonate influence the expression of maternal behaviour in sheep? Behaviour 136, 367-389.

Dwyer CM 2003. Behavioural development in the neonatal lamb: effect of maternal and birth-related factors. Theriogenology 59, 1027-1050.

Dwyer CM, Lawrence AB, Bishop SC, Lewis M 2003. Ewe-lamb bonding behaviours at birth are affected by maternal undernutrition in pregnancy. British Journal of Nutrition 89, 123-136.

Dwyer CM, Lawrence AB 2005. A review of the behavioural and physiological adaptations of extensively managed breeds of sheep that favour lamb survival. Applied Animal Behaviour Science 92, 235260.

Dwyer CM, McIlvaney KM, Coombs TM, Rooke JA, Ashworth CJ 2010. Undernutrition in early to mid pregnancy causes deficits in the expression of maternal behaviour in sheep that may affect lamb survival. In 'Proceedings of the 44th International Society for Applied Ethology (ISAE): coping in large groups'. (Ed. L Lidfors, H Blokhuis, L Keeling) p. 45. (Wageningen Academic Publishers: Wageningen, The Netherlands).
Dwyer CM, Conington J, Corbiere F, Holmøy IH, Muri K, Nowak R, Rooke J, Vipond J, Gautier JM 2016. Invited review: Improving neonatal survival in small ruminants: science into practice. Animal 10:3, 449-459.

Everett-Hincks JM, Dodds KG 2008. Management of maternal-offspring behaviour to improve lamb survival in easy care sheep systems. Journal of Animal Science 86, E259-270.

Everett-Hincks JM, Mathias-Davis HC, Greer GJ, Auvray BA, Dodds KG 2014. Genetic parameters for lamb birth weight, survival and death risk traits. Journal of Animal Science 92, 2885-2895.

Gardner DS, Buttery PJ, Daniel Z, Symonds ME 2007. Factors affecting birth weight in sheep: maternal environment. Reproduction 133(1): 297-307.

Geenty KG, Brien FD, Hinch GN, Dobos RC, Refshauge G, McCaskill M, Ball AJ, Behrendt R, Gore KP, Savage DB, Harden S, Hocking-Edwards JE, Hart K, van der Werf JHJ 2014. Reproductive performance in the Sheep CRC Information Nucleus using artificial insemination across different sheep-production environments in southern Australia. Animal Production Science 54, 715-726.

Goursaud AP, Nowak R 1999. Colostrum mediates the development of mother preference by newborn lambs. Physiology \& behavior. 67(1):49-56.

Hatcher S, Atkins KD, Safari E 2009. Phenotypic aspects of lamb survival in Australian Merino sheep. Journal of Animal Science 87, 2781-2790.

Hatcher S, Eppleston J, Thornberry KJ, Watt B 2010. High Merino weaner survival rates are a function of weaning weight and positive post-weaning growth rates. Animal Production Science 50, 465-472.

Hergenhan RL, Hinch GN, Ferguson DM 2014. Sire effects on neonatal lamb vigour and following-behaviour. Animal Production Science 54, 745-752.

Hinch GN, Brien F 2014. Lamb survival in Australian flocks: a review. Animal Production Science 54, 656666.

Holst PJ, Hall DG, Allan CJ 1996. Ewe colostrum and subsequent lamb suckling behaviour. Australian Journal of Experimental Agriculture 36, 637-640.

Ison S 2016. Neonatal lamb mortality, Murray Local Land Services, Albury. http://www.flockandherd.net.au/sheep/reader/neonatal -lamb-mortality.html (25.04.2017). 
Kenyon PR, Hickson RE, Hutton PG, Morris ST, Stafford KJ, West DM 2012. Effect of twin-bearing ewe body condition score and late pregnancy nutrition on lamb performance. Animal Production Science 52, 483-490.

Kleemann DO, Walker SK, Walkley JRW, Ponzoni RW, Smith DH, Grimson RJ, Seamark RF 1993. Effect of nutrition during pregnancy on birth weight and lamb survival in FecB Booroola - South Australian Merino ewes. Animal Reproduction Science 31, 213-224.

Kleemann DO, Kelly JM, Rudiger SR, McMillen IC, Morrison JL, Zhang S, MacLaughlin SM, Smith DH, Grimson RJ, Jaensch KS, Brien FD 2015. Effect of periconceptional nutrition on the growth, behaviour and survival of the neonatal lamb. Animal Reproduction Science, 160:12-22.

Lambex JT 2014. Lambs to survive and thrive. http://www.moffittsfarm.com.au/2014/09/25/lambs-tosurvive-and-thrive/ (06.04.2017)

Mahoub HDH, Ramadan, SGA, Helal, MAY, Aziz EAK Sameh 2013. Effect of Maternal feeding in late pregnancy on behaviour and performance of Egyptian goat and sheep and their offspring. Global Veterinaria, $11,168-176$.

Maud BA, Duffell SJ 1977. Lamb mortality in relytion to prolificacy Animal Production 24;158-159.

McNeill DM, Murphy PM, Lindsay DR 1998. Blood lactose $v$. milk lactose as a monitor of lactogenesis and colostrum production in Merino ewes. Australian Journal of Agricultural Research 49: 581-587.

Mellor DJ, Stafford KJ 2004. Animal welfare implications of neonatal mortality and morbidity in farm animals. Veterinary Journal (London, England) 168: 307-324.

Nowak R, Poindron P 2006. From birth to colostrum: early steps leading to lamb survival. Reproduction, Nutrition,
Development 46, 431-446.

Oldham CM, Thompson AN, Ferguson MB, Gordon DJ, Kearney GA, Paganoni BL 2011. The birthweight and survival of Merino lambs can be predicted from the profile of liveweight change of their mothers during pregnancy. Animal Production Science 51(9):776-83.

Poindron P, Levy F, Keller M 2007. Maternal responsiveness and maternal selectivity in domestic sheep and goats: the two facets of maternal attachment. Developmental Psychobiology 49, 54-70.

Refshauge G, Brien FD, Hinch GN, van de Ven R 2016. Neonatal lamb mortality: factors associated with the death of Australian lambs. Animal Production Science, $56,726-735$.

Rooke JA, Arnott G, Dwyer CM, Rutherford KMD 2015. The importance of the gestation period for welfare of lambs: maternal stressors and lamb vigour and wellbeing. The Journal of Agricultural Science 153, 497-519.

Safari E, Fogarty NM, Gilmour AR, Atkins KD, Mortimer SI, Swan AA, Brien FD, Greeff JC, van der Werf JHJ 2007. Across population genetic parameters for wool, growth, and reproduction traits in Australian Merino sheep. 2. Estimates of heritability and variance components. Australian Journal of Agricultural Research 58, 177-184.

Sarıcan C 2012. Kuzu kayıplarının önlenmesi, İzmir. http://www.ozevren.com.tr/index.php/makaleler/kuzuk ayiplariveonlenmesi (12.02.2017).

Özdemir S, Altın T 2007. Karya tipi koyunlarda doğum ve doğum sonrası erken dönemde analık davranışları. Hayvansal Üretim Dergisi 48(1): 14-20. 